\title{
No calm after the storm-diaspora influence on bilateral emergency aid flows
}

\author{
Hendrik Platte* \\ Department of Politics and Public Administration, University of Konstanz, Postbox 83, D-78457 Konstanz, Germany \\ ${ }^{\star}$ Corresponding author. Email: hendrik.platte@uni-konstanz.de
}

(Received 22 October 2018; revised 25 February 2019; accepted 3 April 2019; first published online 6 June 2019)

\begin{abstract}
This study analyzes how migrants affect their host country's foreign policy toward their home country by measuring their influence on bilateral emergency aid. I develop the argument that besides political lobbying and the targeting of aid by the donor country, migrants affect emergency aid by providing a linkage between the countries and increasing the salience of a disaster abroad. The empirical analysis shows that the location and size of a country's diaspora is an important predictor of emergency aid flows after natural disasters. Interaction effects provide support for the linkage argument: while the diaspora effect does not increase with the host country's level of democracy, it is strongest with the least severe and most distant disasters.
\end{abstract}

Keywords: Foreign policy; international cooperation and organization; international relations

\section{Introduction}

On March 6, 2007, Sumatra, a large island in western Indonesia, was hit by two waves of an earthquake that reached 6.4 on the moment magnitude scale. With about 460 serious injuries and 60 people killed, the impact of the disaster was comparatively modest, but Indonesia received more than 1.8 million US dollar in bilateral emergency aid. Of the six donor countries, Malaysia $(885,300)$, the Netherlands $(993,400)$, Germany $(11,400)$, and the United Arab Emirates $(6,000)$ host some of the largest Indonesian diaspora communities worldwide. I argue here that migrants affect bilateral emergency aid flows by increasing the attention of the host countries to disasters in the homeland. This effect should be especially relevant the larger the distance of a potential donor from a disaster and for less severe disasters, which otherwise run the risk of going unnoticed in the global news stream. Given that natural disasters kill, impoverish, and severely disrupt the lives of tens of thousands of people every year, the question whether and how disaster-affected countries can profit from exiles abroad is of substantive relevance.

The broader research question this study wants to answer is how migrant groups affect the bilateral relations between their host and their home country. Diasporas are potentially influential actors in foreign policy-making as they reside outside their country of origin, but often maintain strong material and emotional ties to it. The evidence suggests that migrant-sending countries profit through larger trade volumes (Rauch and Trindade, 2002) as well as increased inflows of Foreign Direct Investment (FDI, Leblang, 2010) and foreign aid (Bermeo and Leblang, 2015) from the diaspora's host countries. Under certain circumstances, however, migration also appears to contribute to the diffusion of civil wars (Salehyan and Gleditsch, 2006), interstate conflicts (Salehyan and Gleditsch, 2006), terrorism (Bove and Böhmelt, 2016), and increase the probability of military interventions by the host country (Bove and Böhmelt, 2019). For the US,

(C) The European Political Science Association 2019. This is an Open Access article, distributed under the terms of the Creative Commons Attribution licence (http://creativecommons.org/licenses/by/4.0/), which permits unrestricted re-use, distribution, and reproduction in any medium, provided the original work is properly cited. 
there is a sizable case study literature documenting the influence of "ethnic" interest groups on foreign policy decisions (Smith, 2000). Evidently, migrants have the potential to transform the bilateral relations between their host and their home country, but we still know little about the ways and means of migrant influence across countries.

Bilateral emergency aid in response to natural disasters offers one of the rare benchmarks against which migrant influence on foreign policy outcomes can be measured. In addition, the data on emergency aid allows the researcher to approximate the underlying mechanisms of the diaspora effect: while it has been argued that migration affects aid by (a) governments' attempts to target aid to prevent further migration and (b) by migrants' lobbying efforts, I argue here that migrants do influence emergency aid also by (c) increasing the salience of a disaster event abroad (linkage). As event-driven migration is usually short-lived and takes the form of internal displacement rather than transnational migration, donor countries are generally less likely to target disaster aid to prevent chain migration. If they do, however, the effect of migrant populations should decrease with increasing distance to the disaster-affected country, but increase with growing severity of a disaster, as smaller distances and more severe disasters are expected to contribute to migration. However, the empirical results of the two newly collected datasets on emergency aid flows suggest that the opposite is true: the diaspora effect is largest for the most distant countries and smallest for the most severe disasters. I interpret this, vice versa, as evidence for the attention mechanism: migrants make a difference for disasters that receive little attention in potential donor countries by increasing the host country's awareness of the event. Migrants are further found to be more influential in less democratic host countries, a finding that is easier to reconcile with the idea of a diaspora as information provider than a lobbying force. In an otherwise restricted information landscape, migrants provide an important form of transnational linkage that increases the salience of a disaster event abroad.

By this, the study not only contributes to the research field on migration and foreign policy outcomes, but also adds another aspect to the brain drain and brain gain discussion: migrantsending countries appear not only to profit from remittance inflows and the facilitation of investment and trade (Rauch and Trindade, 2002; Leblang, 2010, 2017), but also from the information emigrants spread. While previous research often simply ascribes political agency to migrant communities, quantitative and cross-sectional empirical evidence supporting this claim is rather scarce. My findings suggest that by increasing the visibility of a disaster in the host country, diaspora members affect donor countries' emergency aid decisions and thus contribute to the recovery of their home country. Broadly speaking, the study adds to our understanding of the medium- and long-term effects of migration: it appears that the mere presence of a large number of people living in exile has the potential to significantly affect the bilateral relations between the home and the host country, and in the case of a natural disaster home countries profit from their diaspora by increased donor attention.

\section{Literature review and arguments}

As there is no commonly agreed upon definition of the term diaspora, expressions like ethnic minority, diaspora interest group, or migrant community coexist and are often used interchangeably in the literature (Rubenzer, 2011, 105). Generally, a diaspora is a group of migrants who maintain a connection, sentimental, material, or familial, to their country of origin (Brinkerhoff, 2011, 116). Driven by data limitations, I rely here on the most basic definition of the term diaspora as a group of people born in one country and living in another (Leblang, $2017,75) .{ }^{1}$ On the left-hand side of the equation, emergency aid given in response to natural disasters is part of humanitarian aid, which is defined as "material or logistical assistance provided

\footnotetext{
${ }^{1}$ Potentially, this could be both an overestimate of the size of the diaspora, because not all migrants maintain an interest in the home country, and an underestimate, as only the first generation of immigrants is considered.
} 
for humanitarian purposes, typically in response to humanitarian crises including natural disasters and man-made disaster." Other than development aid, which seeks to address the underlying socioeconomic factor causes of human suffering, "[t]he primary objective of humanitarian aid is to save lives, alleviate suffering, and maintain human dignity" (Tierney, 2016).

An extensive case study literature on "ethnic interest groups" finds migrants to organize and function just like domestic interest groups in seeking influence over decision-makers in the US (Mearsheimer and Walt, 2008; Rubenzer, 2011). Lahiri and Raimondos-Møller (2000) propose a political-economic model in which a resource-rich migrant lobby can bias aid in favor of a less needy country. Given the specific openness of the pluralistic US political system to organized interests (Smith, 2000, 94), however, it remains unclear whether the interest group model is justified within a cross-sectional setting. While there is plenty of anecdotal and case study evidence on instances of migrant lobbying, quantitative evidence across countries is rather scarce: Bermeo and Leblang (2015) argue that migration increases development aid because host country governments target aid to prevent further migration and due to migrants' political lobbying. The authors find some evidence for the latter mechanism with the help of a mobilization index, indicating whether host countries give voting rights to immigrants and if home countries mobilize their diaspora by granting dual citizenship. With basically the same arguments, Bove and Böhmelt (2019) hypothesize that host countries are more likely to intervene in civil wars of their immigrants' home countries to prevent refugee inflows and due to the political lobbying of the diaspora. Accordingly, they expect the migrant influence to grow with the level of host country democracy but find only limited evidence in support of this hypothesis. Finally, qualitative evidence by Mirilovic (2018) suggests that both home and host country regime type determine migrants' abilities to spur political cooperation, finding diasporas to be successful lobbies in jointly democratic dyads only.

\subsection{Linkage}

Often, political advocacy is ascribed to diasporas rather than directly tested. Given that diaspora groups often are highly heterogeneous entities, poorly organized, and with limited political access even in democracies, I argue here that besides political lobbying, migrants affect foreign policy outcomes by their function as a channel for information flows and the attention their presence generates in the host country. Via familial, material, and psychological ties and the prospect of return, emigrants often remain tightly connected to their country of origin (Leblang, 2017). By this, bilateral migrant stocks represent an important form of linkage, understood as the density of economic, social, communicative and geographic ties between two countries. Linkage effects are often "diffuse, indirect, and [...] difficult to detect" (Levitsky and Way, 2005a, 25), offering a more structural and (sometimes passive) view of migrant influence. In the democratization literature, dense communication flows and widespread contacts to the West are argued to increase attention to autocratic abuses and hence the pressure to intervene (Levitsky and Way, 2005b).

Similarly, I expect countries with a higher level of linkage to potential donor countries to be more likely to receive foreign assistance in case of disaster: migrant linkages heighten the salience of a disaster abroad by increasing the chances that it becomes news in donor countries. Providing the information about a disaster event is, of course, not enough to convince host country governments to send aid abroad. Rather, I assume the diaspora network to have an amplifying effect, in the sense that migrants disseminate the news of a disaster via the media or because the media pays more attention to the migrants' home country. Several studies have found news reporting of natural disasters abroad to positively affect aid flows (Drury et al., 2005; Rioux and Belle, 2005), emphasizing the relevance of attention to a disaster in the decision-making process on aid. Eisensee and Strömberg (2007) have shown how natural disasters abroad compete with other events for attention, but if a disaster is covered in the US television news, the probability 
to receive emergency aid is significantly higher. ${ }^{2}$ Similarly, diasporas are well-known to engage in fundraising after disasters to support the victims back home. ${ }^{3}$ Yang $(2008,33)$ finds remittances to be counter-cyclical, increasing in response to a disaster and providing a lifeline of support to victims before other resources of support are available. These activities draw public attention in the host countries and can spur further aid flows by the government. With these amplifying effects, even disasters of rather modest severity or in large distance can receive substantial attention in donor countries, and hence create influential constituencies for foreign assistance. Together, these factors are expected to increase the pressure on decision-makers to grant assistance for recovery.

While all forms of linkage are expected to increase aid after disasters, migrant linkages are special: through the close cultural and familial links migrants maintain to their home countries, migrant networks will allow for transfers of resources and information which "are both more salient and more likely than in networks of less similar members because of the strong ties associated with kinship and familiarity" (Miller and Ritter, 2014, 54). Empirical evidence suggests that this flow of information facilitates remittances (Leblang, 2017), trade (Rauch and Trindade, 2002), and investment (Leblang, 2010). Communication channels further enable emigrants to "remit" democracy (Pérez-Armendáriz and Crow, 2010), to inform about immigration policies (Helbling and Leblang, 2019), and (under certain circumstances) to reduce the likelihood of conflict occurrence in the homeland (Miller and Ritter, 2014). At the same time, migration can contribute to the diffusion of civil wars (Salehyan and Gleditsch, 2006), interstate conflicts (Salehyan and Gleditsch, 2006), terrorism (Bove and Böhmelt, 2016), and increase the probability of military interventions by the host country (Bove and Böhmelt, 2019). Together, these findings suggest that migrants not necessarily exert influence as advocates of the homeland, but as information channels that can be both to the advantage and disadvantage of the homeland government.

If the information about a disaster and its impact transmitted via migrant networks increases the awareness of a disaster within host countries, I expect the higher level of attention to translate into higher aid flows. While the effects of linkage are often diffuse, indirect, and difficult to detect (Levitsky and Way, 2005b, 523), emergency aid after natural disasters serves as a way to measure the effect of migrant linkages in bilateral relations. Rather than through their lobbying power and access to decision-makers, the linkage argument suggests that a diaspora's presence and engagement in disseminating information and raising money translates into public pressure on the government to send aid in support of disaster victims. This effect is expected to be especially relevant for more distant and less severe disasters, which typically receive less attention in the donor country. The effect should be independent of the host country's regime type, as migrant linkage effects do not require direct access to decision-makers, but work indirectly via media attention and fundraising spillover effects.

\subsection{Lobbying}

Beyond providing information, migrants may affect aid by lobbying their host country government, as disasters can serve as a focal point for diaspora mobilization on behalf of the homeland. In addition to fundraising and the dissemination of information, members of the diaspora also become involved by offering in-kind support and connections to social networks. Their high degree of access, local knowledge, and ability to respond and mobilize quickly make them valuable assets for their homeland and can improve the effectiveness of humanitarian responses (Bostrom et al., 2016). Enhanced information and communication technologies today enable

\footnotetext{
${ }^{2}$ To shed some light on the diaspora-media attention nexus, I rely on Eisensee and Strömberg's (2007) replication data to show that migrant populations are positively correlated with media attention to a disaster, and migrant populations and news reporting jointly increase aid (see Appendix).

${ }^{3}$ As e.g. after the 2001 Bhuj earthquake in India, https://www.nytimes.com/2001/01/29/world/earthquake-india-responseus-indian-americans-mobilize-send-aid-home.html (02/2019).
} 
migrants to stay in close contact with their relatives at home, creating an "illusion of spatial contiguity" (Adamson and Demetriou, 2007, 508), which facilitates a timely and efficient diaspora response and fortifies its mobilization in times of crisis. These actions can then spill over into lobbying the host country government in favor of emergency assistance to the homeland.

Collective action theories suggest that smaller groups find it easier to organize, as they face less severe problems with free riders and the question who contributes to the group's welfare (Olson, 1974; Saideman, 2002, 98). The special ties that bind migrants to the home country, but also to each other, are of additional help in generating political clout through collective action. Migrants' lobby power, however, will be conditioned by the political rights they enjoy in the host country. As Shain and Barth $(2003,464)$ argue, the regime type critically affects whether and how migrants organize and exert influence, as well as the degree of accountability to migrants' demands. While democracies facilitate organization and lobbying, non-democratic regimes discourage or prohibit civil society activities. Migrants will face higher barriers to access in authoritarian regimes and will also be more likely to be temporary (e.g. in guest-worker programs) than migrants to democratic regimes, which will affect their behavior in the host country. From the lobbying perspective, migrants should have a stronger effect on aid in democracies than in autocracies.

\subsection{Targeted emergency aid}

Finally, host countries may target emergency aid to prevent further immigration due to the impact of a disaster. Bermeo and Leblang (2015) as well as Bove and Böhmelt (2019) argue that host countries send development aid and troops to prevent "chain migration:" as diasporas exert a network effect by decreasing the transaction costs of relocation and integration (Fitzgerald et al., 2014), emigrants often choose destination countries that already host a larger number of compatriots. By sending aid to the home countries of their immigrants, host countries try to increase living standards and reduce the utility of emigration in general and specifically the demand for entry to the donor country (Berthélemy et al., 2009). Donor countries, however, are unlikely to target emergency aid for the same reasons: event-driven migration is usually shortlived and takes the form of internal displacement rather than transnational migration. Evidence suggests that natural disasters do not systematically increase migration flows (Breunig et al., 2012, 20), as people tend to return to their home after a relatively short period of time (Black et al., 2011). While humanitarian assistance is per definition aimed at helping (potential) refugees within their home country, the targeted aid argument predicts that donor countries will send aid specifically to those people which they expect to come to their country otherwise. From the targeted aid perspective, the diaspora effect should increase with decreasing distance to the disaster, as migration costs increase with distance. Similarly, the diaspora effect should increase with the severity of a disaster, as disasters that cause more destruction will force more people to leave their home country.

\subsection{Synopsis}

To summarize, there are three mechanisms by which migrants may affect bilateral emergency aid flows to their country of origin: First, host countries may target emergency aid to prevent further inflows from their immigrants' home countries in the wake of natural disasters. The targeted aid argument sees migrants in an entirely passive role but is expected to be less relevant in the context of emergency aid. Second, the lobbying argument suggests that migrants influence their host country's aid decisions by their political advocacy on behalf of the home country. For this effect to materialize, however, certain rights and some degree of access to the host country's political system are necessary. Less organized, more diverse, and politically excluded migrant communities will find it much harder to generate political clout to positively affect donor countries aid decisions. Third, the linkage approach ascribes a less politicized role to the diaspora: the mere 
presence of a large migrant community in the donor country will increase the level of attention a disaster in the migrants' home country receives. Migrant ties enable information flows of a more direct and more salient nature than would be the case in the absence of such ties, and the increased awareness of a disaster can translate into public pressure to send aid. While information provision can also be a form of lobbying, the linkage argument does not ascribe political agency to the diaspora, as the information is transmitted via migrant networks irrespective of the migrants' rights in the host country. Enhanced media coverage and diaspora fundraising are two channels by which migrants can enhance public scrutiny and exert pressure on decisionmakers to act.

\section{Hypotheses}

Be it due to migrants' political lobbying, the increased salience that a disaster in the home country experiences in the host country, or because donors target aid to mitigate effects of chain migration, the unconditional diaspora effect on emergency aid should be positive. The first hypothesis reflects this expected aggregate relationship:

HYPOTHESIS 1: The larger the diaspora of a disaster-affected country in a potential donor country, the more likely it is to receive aid and the higher the amount.

While migration in response to natural disasters tends to be internal and temporary, host countries may still fear the network effect of diasporas and target aid accordingly to their home countries. If this is the case, the effect of migrant stocks on emergency aid should increase with decreasing distance, as the costs of migration are negatively correlated with distance. When people decide to join the diaspora in the aftermath of a disaster, they will do so in greater numbers the smaller the distance to the destination country. The more distant a host country is, the lower the probability of a larger migration influx. A similar logic should pertain to the impact of a disaster: the more severe the consequences of a natural disaster are, the more people may choose to emigrate and join their friends and relatives abroad, and the more concerned host countries should be with the prevention of migration.

If, however, migration affects emergency aid rather by providing a channel of information, distance and disaster severity should have the opposite effect: to the degree that distance works as a proxy for the cultural and normative differences between a pair of countries, donor countries will pay less attention (and therefore also send less aid) to disaster events in more distant countries. For example, a disaster in a European country will face much lower barriers in generating the attention of Germany as a donor when compared to a similar event in, for example, Indonesia. As outlined in the introduction, however, the presence of a migrant community can make a crucial difference by increasing the salience of an event, and this effect should be the more relevant the more distant a disaster is. Similarly, the more severe a disaster, the more attention it is assumed to generate in a donor country and the more aid it will receive: the information effect of migrant links will have little additional effect here, as the catastrophes with the largest impact tend to receive a lot of news coverage. The linkage approach therefore suggests that the diaspora effect is inversely related to the impact of a disaster: the less severe the consequences of a disaster, the more will the presence of a diaspora in the donor country matter, as migrant networks increase the chances that the disaster becomes news in the donor country. The predictions of the lobbying approach, finally, are somewhat ambiguous: On the one hand, migrant lobbying will be less relevant for nearby and very severe disasters, as they generate major aid flows anyways. On the other hand, more severe disasters should cause stronger mobilization by the diaspora.

Therefore, I formulate the following hypothesis (while the opposite should hold if donor countries target emergency aid): 
HYPOTHESIS 2: If migrants affect emergency aid by providing a linkage between the home and the host country, the diaspora effect should increase with the distance to the homeland and decrease with the severity of a disaster.

Finally, I test the variance of the diaspora effect across the host country's regime type: the literature unanimously agrees that the inclusiveness of host country institutions critically shapes the degree to which migrants can voice their demands, but offers only sparse or conditional empirical support for this claim (Mirilovic, 2015; Bove and Böhmelt, 2019). If, however, the migrant effect works via the linkage channel, we would expect the size of a diaspora community to affect aid irrespective of the host country's regime type, as migrants may increase the salience of a disaster in autocratic contexts as well. While non-democratic regimes limit the freedom of expression and the media, the personal ties of migrant networks are able to circumvent restrictions and transport the news of a disaster to the host country. In addition, diaspora groups can mobilize for fundraising events in autocratic host countries as well, ${ }^{4}$ drawing attention to the disaster in the homeland. To the degree that migrant ties increase the salience of a disaster in an otherwise restricted information context, the diaspora effect might be even more relevant in less- and non-democratic host countries.

If migrants lobby decision-makers in favor of sending aid to the homeland after natural disasters, however, the following relationship should persist:

HYPOTHESIS 3: Migrants residing in democratic host countries are more likely to positively affect emergency aid flows than their counterparts in autocratic host countries.

\section{Data and research design}

Information on the timing, location, and impact of natural disasters comes from the EmergencyEvents Database (EM-DAT), maintained by the Center for Research on the Epidemiology of Disasters (CRED). ${ }^{5}$ A disaster is defined as a natural event or situation which overwhelms local capacity and/or necessitates a request for external assistance. While this definition is potentially endogenous to a country's need for assistance and the database is susceptible to reporting biases (Guha-Sapir et al., 2004), it is the most comprehensive source of information on natural catastrophes of all kinds and the standard data source employed in the literature. Floods, landslides, extreme temperatures, storms, earthquakes, volcanic activities, droughts, and wildfires are included in the analysis. I use the information on timing and location to merge disaster characteristics with aid records and approximate the impact of a disaster with the count of people killed and affected, which prior studies have found to be consistent predictors of aid commitments (Raschky and Schwindt, 2012). ${ }^{6}$

AidData (Version 3.0, Tierney et al., 2011) provides information on both humanitarian and development aid flows. I summarize the four types of emergency aid distinguished by the OECD Creditor Reporting System (CRS $)^{7}$ by dyad year. While the OECD-based data is a standard source in the literature on development aid (e.g. Dreher et al., 2011), it is rarely used in studies of emergency assistance. On the one hand, the OECD-data is based on actual disbursements rather than pledges or commitments and is argued to be the most comprehensive data source on emergency aid (Becerra et al., 2015, 564). On the other hand, however, the database also covers

\footnotetext{
${ }^{4}$ As e.g. the Filipinos in Dubai after Typhoon Haiyan, https:/www.ft.com/content/aaalf450-4db9-11e3-b15d00144 feabdc0 (02/2019).

${ }^{5}$ http://www.emdat.be/ (05/2017).

${ }^{6}$ I rely on the number of people affected to test Hypothesis 2. The Appendix includes robustness test with the number of people killed by a disaster and replications for the OECD-sample.

${ }^{7}$ https://www.oecd.org/dac/stats/purposecodessectorclassification.htm; I exclude funds related to disaster prevention and preparedness.
} 
aid given in response to man-made crises and is aggregated to the dyad-year level, so that aid flows cannot be linked to specific disasters or disaster types. Therefore, studies on the determinants of bilateral disaster relief almost exclusively rely on the Financial Tracking Service (FTS) by the UN Office for the Coordination of Humanitarian Affairs (OCHA), ${ }^{8}$ which provides data for each appeal separately and covers donations by basically every country in the world. However, while the DAC-donors are obligated to report aid donations to the OECD, the UN-FTS data is based on voluntary self-reporting. Being aware of the caveats of the two databases, I test the influence of diasporas on bilateral emergency aid flows with both measures.

For information on the size of a disaster-affected country's diaspora in a potential donor country I rely on the Global Bilateral Migrant Database of the World Bank (Özden et al., 2011), which measures the bilateral stock of people born in country A, living in country B in 10-year intervals from 1960 to 2010, primarily based on census data and excluding refugees. ${ }^{9}$ In line with previous work (Bermeo and Leblang, 2015; Bove and Böhmelt, 2019), I use the absolute number rather than the share of migrants in the host country population: practically, migrant numbers in relation to the overall population are commonly extremely small, resulting in share values clustering close to zero. More substantively, relying on stock numbers seems to be more in line with the interest group and linkage arguments outlined above, while share numbers appear to be a more appropriate measure within a median voter-framework. ${ }^{10}$ I use linear interpolation in order to fill in the missing values between data points, assuming that changes in the migrant population between two measurements follow a linear trend (Özden et al., 2011, 26). ${ }^{11}$

I adjust for several confounding factors expected to be correlated with both the size of the diaspora and emergency aid flows. The first set of confounders is associated with the migrants' home country (the potential recipient): beyond the impact of a disaster, the need for outside help (regardless of cause) as well as the number of people forced to emigrate to earn a living are expected to be shaped by a country's population size and level of economic development, which is measured as the Gross Domestic Product per capita (GDP p.c.). Data is obtained from the World Development Indicators of the World Bank ${ }^{12}$ and these variables are also included on the host country (or donor) side of the dyad in order to control for a country's capability to give aid as well as its attractiveness as a target country for migration.

Both aid and migration flows are expected to be influenced by the bilateral ties between two countries: with data from Gleditsch and Ward (2001), ${ }^{13}$ I control for the geographic distance between donor and recipient and test Hypothesis 2. Due to transaction and transportation costs, providing aid and migrating to more distant countries is expected be more expensive than to countries nearby, even when considering advancements in technology and diminished costs of travel (Raschky and Schwindt, 2012; Fitzgerald et al., 2014). From the Correlates of War project (COW Formal Alliances v4.1) (Singer and Small, 1966; Gibler, 2008) I obtain data on defense alliances, while information on shared colonial history and common official language comes from the CEPII (Mayer and Zignago, 2011). These measures have been found to shape aid flows (Fink and Redaelli, 2011) and are expected to function as proxies for the political and cultural closeness between country pairs, as neither migration nor aid flows occur randomly, but follow routes shaped by political and historical ties (Breunig et al., 2012, 9). For similar

\footnotetext{
${ }^{8}$ https://fts.unocha.org/ (05/2017).

${ }^{9}$ Robustness tests find the results to be robust to controlling for refugee stocks as well as the use of a different diaspora measure (see Appendix).

${ }^{10}$ Still, even after controlling for the size of the host country population, larger stock numbers may pick up effects of larger host/donor countries. Robustness tests indicate that the main results hold with diaspora shares as well (see Appendix).

${ }^{11}$ Unfortunately, the cross-sectional time series migration data does not provide further information on group characteristics. Among other things, geographical concentration or the differing representation of ethnic and regional groups across host countries would be especially relevant information.

${ }^{12} \mathrm{http}$ ://databank.worldbank.org/data/reports.aspx?source=world-development-indicators (01/2017).

${ }^{13} \mathrm{http}: / /$ privatewww.essex.ac.uk/ ksg/data-5.html (01/2017).
} 
reasons, I also include a measure of overall export flows from the donor to the recipient (COW Trade v4.0, Barbieri et al., 2009; Barbieri and Keshk, 2016). In order to test Hypothesis 3, information on the political institutions of donor and recipient countries comes from the Polity IV project of the Center for Systemic Peace Marshall et al. (2017). ${ }^{14}$ The combined democracyautocracy score measures political rights on a scale from -10 (most autocratic) to +10 (most democratic).

The data collection results in two samples of the following form: I observe emergency aid flows from OECD-donor countries from 1990 to 2011, including every country as a potential donor that provided at least three times some form of emergency relief during the sample period, which leaves me with 27 donors. On the recipient side, I consider every country that received some emergency aid during the sample period and for which EM-DAT reports a disaster, resulting in a set of 158 recipient countries. Due to the aggregation of the OECD-data, the data structure comes in the form of directed dyads with annual observations. The UN-sample covers the period 2000-2016, with a much more diverse set of donors, of which many rarely provide aid. Restricting the sample to donors that gave at least ten times results in a set of 48 donors and 102 recipients which received aid at least once during the sample period. Manual matching produces a sample of 302 disasters with the disaster-dyad-year as the unit of analysis.

While disasters happen quite frequently, aid flows do less so: the dependent variable equals zero in many dyads, as only the biggest donors give aid to a large number of disasters. Given the truncated nature of the aid variable, I rely on nonlinear Tobit models to test the relation between aid flows and my explanatory variables (Fink and Redaelli, 2011). The Tobit model jointly estimates the zeros and the logged amount of aid transferred, assuming that the same set of variables determines both whether a country is selected as aid recipient and how much aid is being allocated. ${ }^{15}$ I exploit the (quasi-)panel structure of the datasets and include donor, recipient, and year dummies to control for unobserved country-specific effects as well as common time shocks. The data structure of the UN-sample allows me to control additionally for disastertype specific effects. All continuous variables are log transformed (after adding +1 ) in order to account for the skewed distribution with some very high values of these variables. ${ }^{16}$

\section{Empirical analysis of the diaspora effect on emergency aid flows}

Tables 1 and 2 show the results and substantive effect calculations for the link between migrant populations and emergency aid. The Tobit models are calculated with the logged (one plus) amount of aid as the dependent variable and left-censoring at zero. Since coefficients cannot be interpreted directly in nonlinear models (Wooldridge, 2010), all tables display marginal effects instead, calculated as the effect of the independent variable on the latent (unobserved) variable, multiplied by the probability of being uncensored. With both the OECD- and the UN-data (M1 and M2), I find consistent support for H1: the size of a diaspora is, at conventional levels of statistical significance, positively correlated with bilateral emergency aid flows when the diaspora's home country is hit by a disaster. To gain an idea of the magnitude of the diaspora influence on disaster aid, Table 2 displays substantive effects across models: ${ }^{17}$ with covariates set to their

\footnotetext{
${ }^{14}$ Periods of regime transition and interruption are set to missing, while periods of interregnum are replaced with a zero.

${ }^{15}$ Using a Tobit model on a dependent variable with many zeros and very small as well as very high values might be problematic (Silva and Tenreyro, 2006). However, results prove robust to the use of a series of alternative models and specifications of the dependent variable (see Appendix).

${ }^{16}$ While the log-transformation is common practice in the literature, few authors justify this decision. I rely here on the natural logarithm of the continuous variables in order to align the different scales on which variables are measured and allow for easier comparisons. Indeed, regressing emergency aid on the untransformed independent variables generates results that are hard to interpret as coefficient sizes differ tremendously. However, while the log-transformation is routinely used to deal with "strongly" positively skewed distributions, it potentially under-weighs the effect of large-value observations.

${ }^{17}$ Generated with the help of the moreClarify software (Márquez Peña, 2014).
} 
Table 1. Pooled tobit models, impact of migrant stocks on aid flows

\begin{tabular}{|c|c|c|c|c|c|}
\hline & $\mathrm{M} 1$ (OECD) & M2 (UN) & M3 (OECD) & M4 (UN) & M5 (UN) \\
\hline \multirow[t]{2}{*}{ Diaspora } & 0.054 & 0.114 & -0.185 & 0.328 & 0.125 \\
\hline & $(0.014)^{\star \star \star}$ & $(0.026)^{\star \star \star}$ & $(0.110)^{\star}$ & $(0.068)^{\star \star \star}$ & $(0.026)^{\star \star \star}$ \\
\hline \multirow[t]{2}{*}{ Deaths } & 0.167 & 0.563 & 0.167 & 0.562 & 0.562 \\
\hline & $(0.012)^{\star \star \star}$ & $(0.033)^{\star \star \star}$ & $(0.012)^{\star \star \star}$ & $(0.033)^{\star \star \star}$ & $(0.033)^{\star \star \star}$ \\
\hline \multirow{2}{*}{ Affected } & 0.065 & 0.010 & 0.065 & 0.125 & 0.011 \\
\hline & $(0.008)^{\star \star \star}$ & $(0.029)$ & $(0.008)^{\star \star \star}$ & $(0.044)^{\star \star \star}$ & $(0.029)$ \\
\hline \multirow[t]{2}{*}{ Affected $\times$ diaspora } & & & & -0.016 & \\
\hline & & & & $(0.005)^{\star \star \star}$ & \\
\hline \multirow[t]{2}{*}{ Former colony } & 0.745 & 0.839 & 0.748 & 0.809 & 0.962 \\
\hline & $(0.121)^{\star \star \star}$ & $(0.278)^{\star \star \star}$ & $(0.121)^{\star \star \star}$ & $(0.279)^{\star \star \star}$ & $(0.282)^{\star \star \star}$ \\
\hline \multirow[t]{2}{*}{ Common language } & 0.590 & 0.734 & 0.568 & 0.724 & 0.774 \\
\hline & $(0.084)^{\star \star \star}$ & $(0.181)^{\star \star \star}$ & $(0.085)^{\star \star \star}$ & $(0.181)^{\star \star \star}$ & $(0.182)^{\star \star \star}$ \\
\hline \multirow[t]{2}{*}{ Alliance } & -0.590 & -0.537 & -0.565 & -0.589 & -0.538 \\
\hline & $(0.152)^{\star \star \star}$ & $(0.290)^{\star}$ & $(0.152)^{\star \star \star}$ & $(0.291)^{\star \star}$ & $(0.290)^{*}$ \\
\hline \multirow{2}{*}{ Distance } & -0.745 & -0.681 & -0.959 & -0.620 & -0.732 \\
\hline & $(0.076)^{\star \star \star}$ & $(0.130)^{\star \star \star}$ & $(0.124)^{\star \star \star}$ & $(0.131)^{\star \star \star}$ & $(0.131)^{\star \star \star}$ \\
\hline \multirow[t]{2}{*}{ Distance $\times$ diaspora } & & & 0.028 & & \\
\hline & & & $(0.013)^{\star \star}$ & & \\
\hline \multirow{2}{*}{ Exports donor to recipient } & 0.214 & 0.244 & 0.213 & 0.246 & 0.232 \\
\hline & $(0.026)^{\star \star \star}$ & $(0.049)^{\star \star \star}$ & $(0.026)^{\star \star \star}$ & $(0.049)^{\star \star \star}$ & $(0.050)^{\star \star \star}$ \\
\hline \multirow[t]{2}{*}{ Democracy donor } & & 0.071 & & 0.069 & 0.108 \\
\hline & & $(0.095)$ & & $(0.095)$ & $(0.096)$ \\
\hline \multirow{2}{*}{ Democracy donor $\times$ diaspora } & & & & & -0.006 \\
\hline & & & & & $(0.002)^{\star \star \star}$ \\
\hline \multirow{2}{*}{ Democracy recipient } & -0.006 & 0.151 & -0.006 & 0.152 & 0.151 \\
\hline & $(0.008)$ & $(0.023)^{\star \star \star}$ & $(0.008)$ & $(0.023)^{\star \star \star}$ & $(0.023)^{\star \star \star}$ \\
\hline \multirow[t]{2}{*}{ Population donor } & 7.105 & 4.852 & 7.106 & 4.877 & 5.118 \\
\hline & $(0.986)^{\star \star \star}$ & $(0.890)^{\star \star \star}$ & $(0.987)^{\star \star \star}$ & $(0.893)^{\star \star \star}$ & $(0.904)^{\star \star \star}$ \\
\hline \multirow[t]{2}{*}{ GDP p.c. donor } & 1.321 & 1.771 & 1.325 & 1.786 & 1.818 \\
\hline & $(0.196)^{\star \star \star}$ & $(0.353)^{\star \star \star}$ & $(0.196)^{\star \star \star}$ & $(0.354)^{\star \star \star}$ & $(0.354)^{\star \star \star}$ \\
\hline \multirow[t]{2}{*}{ Population recipient } & 1.076 & -3.033 & 1.101 & -2.842 & -3.057 \\
\hline & $(0.398)^{\star \star \star}$ & $(2.315)$ & $(0.398)^{\star \star \star}$ & $(2.320)$ & $(2.314)$ \\
\hline \multirow[t]{2}{*}{ GDP p.c. recipient } & -0.789 & 0.252 & -0.789 & 0.239 & 0.258 \\
\hline & $(0.096)^{\star \star \star}$ & $(0.376)$ & $(0.096)^{\star \star *}$ & $(0.377)$ & $(0.376)$ \\
\hline$N$ & 45489 & 9214 & 45489 & 9214 & 9214 \\
\hline Donors & 26 & 44 & 26 & 44 & 44 \\
\hline Recipients & 131 & 78 & 131 & 78 & 78 \\
\hline Dyads & 3373 & 3351 & 3373 & 3351 & 3351 \\
\hline
\end{tabular}

The dependent variable is the log of ( 1 plus) emergency aid commitments from the donor to the recipient. Reported are marginal effects calculated as the effect on the latent variable multiplied by the probability of being uncensored. All models include donor, recipient, and year dummies (M2, M4, and M5 additionally disaster-type dummies); standard errors in parentheses. ${ }^{\star} p<0.1,{ }^{\star \star} p<0.05$, ${ }^{\star \star \star} p<0.01$

mean values, the Table shows the (simulated) percentage change in aid when increasing the migrant stock measure by one standard deviation from its sample mean value. While Model 1 predicts a 2.4 percent growth in disaster aid by OECD-donors with increasing diaspora size, simulations based on Model 2 predict an 8.4 percent increase in aid for the UN-sample. ${ }^{18}$

Hypothesis 2 is tested in Model 3 and 4 by interacting the migrant stock measure with the distance between donor and recipient as well as the severity of a disaster, measured by the number of people affected. Since the coefficient signs and standard errors of interaction terms in nonlinear models cannot be interpreted in a straightforward way (Ai and Norton, 2003), I proceed by plotting the marginal effect of migrant populations on aid across distance and disaster impact (Greene, 2010). Figure 1 displays the average effect of increasing the migrant stock by one unit

\footnotetext{
${ }^{18}$ The generally higher predictions for the UN-sample might be due to the restriction to (more) frequent donors or the stronger responsiveness of less- and non-democratic donors to their migrant communities (see below). While effect sizes might appear rather small, donor, recipient, and year fixed effects absorb a substantial part of the cross-sectional variance. After all, migrants are not expected to drive their host country's aid policy, but to affect disaster assistance at the margins.
} 
Table 2. Diaspora effect on emergency aid-substantive effects calculations

Table displays the predicted percentage change in aid when increasing the diaspora stock by one standard deviation from the mean, with covariates set to their mean values.

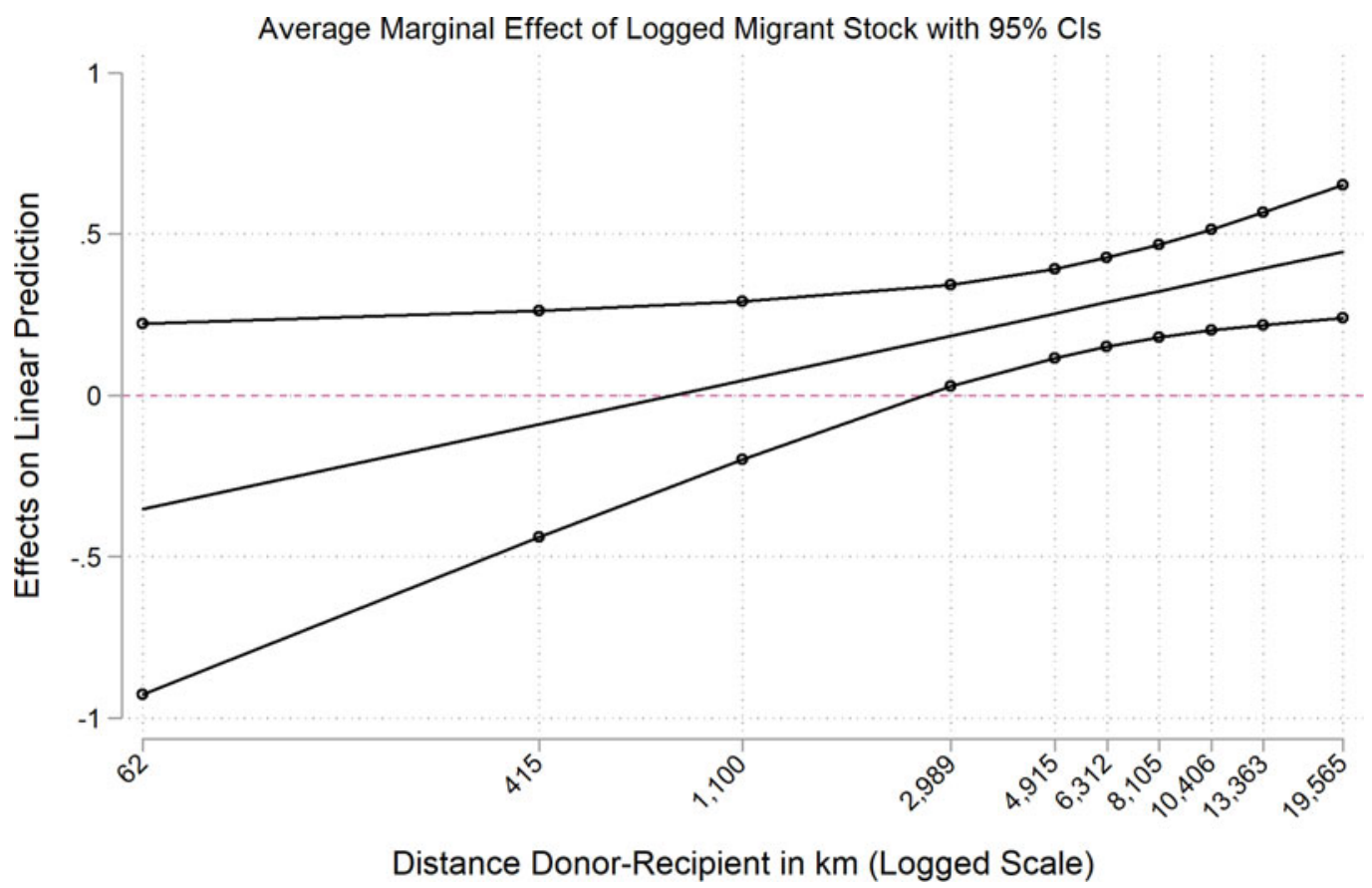

Figure 1. Interaction of bilateral distance and migrant stock, OECD-sample (M3)

over distance as the continuous line, while the dotted lines mark the 95 percent confidence intervals: as evident from the upward slope, the interaction effect between distance and migrant population is positive. With very large distances of a potential donor country to a disaster, larger migrant populations from the disaster-affected country significantly increase aid. The substantive effect calculation even suggests that larger migrant populations decrease aid by 6.3 percent for the closest countries, though this effect is not statistically different from zero. ${ }^{19}$ For the most distant donor countries, however, aid is predicted to grow by 3.5 percent when increasing the size of the diaspora by one standard deviation from the mean. ${ }^{20}$

Figure 2 plots the effect of migrant populations over the number of people affected by a disaster. The graph shows a clear negative relation: the higher the number of people affected by a

\footnotetext{
${ }^{19}$ It is not intuitively clear why the effect might be negative for the closest countries. One possible explanation is that OECD-countries give most of their aid not to their rather affluent neighborhood, but to somewhat more distant and less developed countries-an effect that will be reinforced by the presence of migrants.

${ }^{20}$ Replicating the interaction for the UN-sample finds the result to be robust (see Appendix).
} 


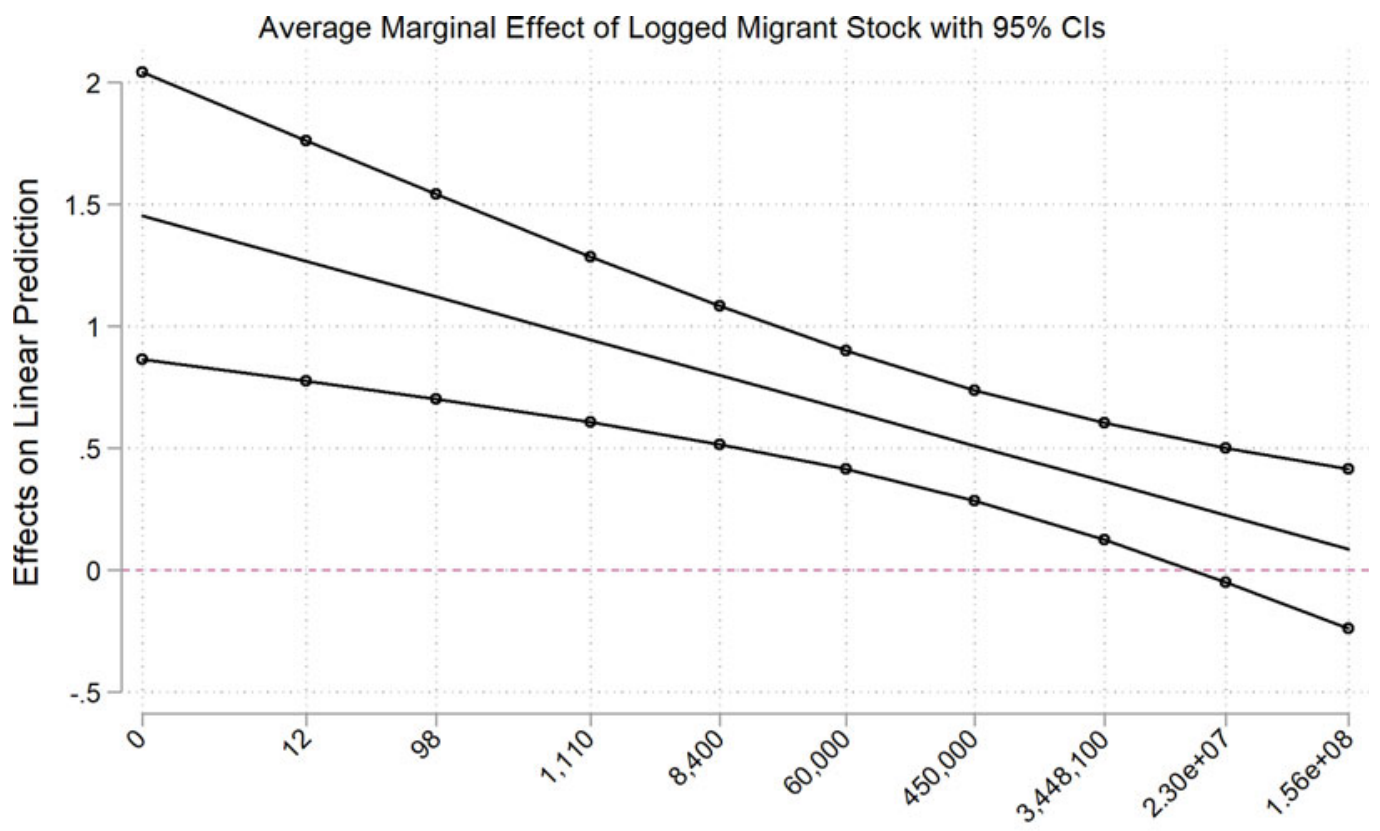

Number of People Affected (Logged Scale)

Figure 2. Interaction of disaster impact and migrant stock, UN-sample (M4)

disaster, the smaller the effect of migrant populations on aid. According to the substantive effects calculation, increasing the migrant population at the lowest level of disaster impact corresponds to a 21.7 percent surge in aid flows, while aid increases only by 1.7 percent for the most severe disaster. Both findings speak against the idea that host countries target aid to prevent further migration from countries of which they already host a sizable diaspora: if so, the diaspora effect should decrease with distance, as migration pressure will be strongest for the countries closest to a disaster. The diaspora effect should also increase with the number of people affected by a disaster, as more severe disasters are expected to increase the pressure to migrate. Finding the opposite relationship in both cases is more in line with the idea of migrants as messengers: in general, the further away and the less severe a disaster is, the less attention (and subsequently aid) it will receive from a potential donor country (see results for distance and number of people affected in M1 and M2). Migrant populations can make a crucial difference here, as their presence in the host country and the ties they maintain to the homeland increase the probability that news about a disaster make it to the donor country. By this, migrants increase the salience and awareness of a disaster abroad and positively affect aid. Mobilization effects seem to be less important and/or offset by the direct effect of disaster severity on aid.

Figure 3 plots the interaction effect between migrant stocks and the Polity score of the host country: surprisingly, the downward slope of the diaspora effect indicates that emigrants to democratic countries appear to affect emergency aid to their home country less than their counterparts in autocratic host countries. Increasing the diaspora stock by one standard deviation from its sample mean value is associated with a 5.2 percent rise in aid for the most democratic donors, but 10.3 percent for autocratic donors. This finding contradicts the idea of migrants as lobbyists in the host country but is more in line with the information mechanism outlined above: while diaspora communities will find it hard to organize as lobby groups and exert influence in autocratic regimes, migrant ties to the home country can still transport information about a disaster. The linkage effect may be especially relevant in autocratic regimes that restrict other 


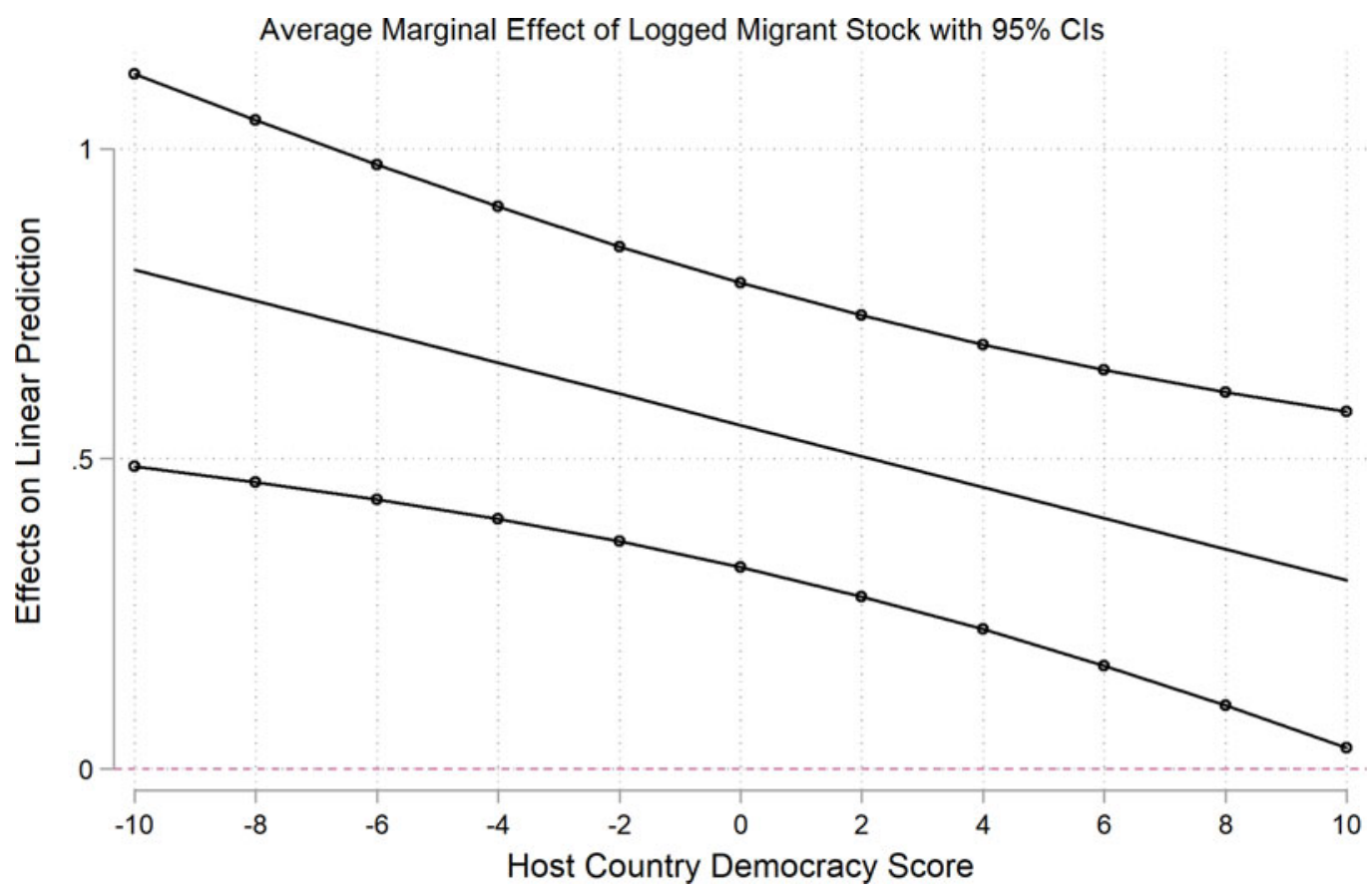

Figure 3. Interaction of donor regime type and migrant stock, UN-sample (M5)

communication channels, assigning diaspora groups a special role as messengers of a disaster abroad. Diaspora members are further able to engage in fundraising, which can translate into increased government-to-government aid.

A look into the data reveals that countries of the former Soviet Union often give aid to past sister states of which they host many immigrants. ${ }^{21}$ Russia, for example, gives aid to countries like Azerbaijan, Moldova, Tajikistan, or Ukraine, while the rich Gulf monarchies frequently assist their guest-workers' home countries when hit by a disaster: the United Arab Emirates send aid to Bangladesh, Pakistan, and the Philippines; Saudi Arabia to the same countries as well as Sri Lanka, Sudan, and Indonesia. Guest-workers in the rich Arab oil states are largely deprived of political rights and will hardly have any political clout, but via their ties to their country of origin information on the consequences of a disaster at home is transmitted to the host country. On the supply-side, it is not intuitively clear why autocratic regimes should be more responsive to their immigrants, as we know little about the general motivations to give "rogue aid" (Fuchs and Klann, 2012; Dreher et al., 2013). One possible explanation is that many of the autocratic donors in the sample rely on foreign workforces: to the degree that they view immigrants as an important resource or "import," decision-makers may want to stay on friendly terms with the migrantsending country and try to convey a positive image as a host country. Humanitarian aid is one form of soft power by which autocratic donors attempt to improve their reputation and win hearts and minds abroad. ${ }^{22}$ Al-Yahya and Fustier $(2011,27)$ suggest that Saudi Arabia's relief efforts in the home countries of its expatriate population are guided by security concerns, as providing humanitarian relief "helps ease tensions that might exist with the expatriate population."

\footnotetext{
${ }^{21}$ See Online Appendix for details.

${ }^{22}$ Non-DAC donors are especially active in humanitarian assistance (Dreher et al., 2013, 402).
} 
Rather than through lobbying, emigrants to Saudi Arabia seem to affect aid through the perceived consequences of their presence. $^{23}$

Regarding the covariates, most results are in line with the previous literature on emergency aid. Overall, donors' aid decisions appear to be responsive to the need caused by a disaster: the number of people killed is a consistent predictor of aid flows in both samples, albeit the comparative magnitude of the effect is larger in the UN-sample, which allows to link aid flows more directly to specific disasters. More populous and affluent countries tend to give more aid, but results are more mixed concerning recipient need independent of cause: while the recipients of OECD aid tend to be more populous and less affluent, both population and GDP p.c. are insignificant in the UN-sample. Recipient democracy, on the other hand, is positively correlated with aid in the UN-sample, but insignificant in the OECD-sample. Finally, regarding bilateral controls, countries that share a colonial history with a donor country, have a common official language and import more goods from the donor are consistently found to receive higher amounts of emergency aid. Vice versa, defense allies and more distant countries receive less aid.

\section{Conclusion}

It appears that for countries which are hit by a disaster, emigration is a "mixed blessing:" while migrant-sending countries experience several negative brain drain effects, they may not only profit from brain gain in the form of return migration, increased remittances, trade, and investment flows, but also from increased aid contributions by the diaspora's host countries. As in the case of the 2007 earthquake in Indonesia, bilateral emergency aid across countries and over time is systematically correlated with the location and size of a country's diaspora, and this effect is more relevant for distant and less severe disasters. Surprisingly, autocratic donors appear to be somewhat more responsive to their immigrant communities than democratic donors. I interpret these findings as support for the linkage argument: by providing channels of information, diaspora communities ensure that even remote and comparatively modest disaster events receive attention by their host country. Natural disasters abroad compete with other events for attention in the donor country, and migrant ties can make a crucial difference by increasing the salience of a disaster event. Similarly, the enhanced effect of diasporas in autocratic host countries is consistent with the idea of migrant networks that provide important communication ties in an otherwise restricted information landscape.

Overall, the results suggest that the well-documented private post-disaster engagement of migrants in the form of remittances, fundraising, and volunteering translates into increased donations by the host country. After moving abroad, many migrants maintain close ties to their home country: through their familial connections and the prospect of return, diaspora members identify themselves as part of the homeland's community and are concerned with its security and well-being. Information about events in the home country is therefore transmitted faster than would otherwise be the case. Crisis events like natural disasters can also mobilize migrants to raise the level of attention to the situation in their home country. By this, migrants spur marginal increases in aid, which might be negligible from the donor perspective, but can make a meaningful contribution to the recovery of the homeland. While the causes and consequences of migration flows have received a lot of attention, this study shows that emigration can have positive long-run effects for countries in times of crisis. By applying the linkage approach to bilateral emergency aid, the study offers a more nuanced view of the role of migrants in international relations: migrants have the potential to significantly affect the relations between their host and their home country, but they do so not necessarily as lobbyists.

\footnotetext{
${ }^{23}$ Still, the finding should be treated with some caution: the number of autocratic regimes in the sample is rather small and the UN-data is based on self-reporting. While especially non-DAC donors are suspected to underreport their donations (Harmer and Martin, 2010), autocratic regimes may also have incentives to over-report transfers.
} 
I have focused here on the channels of influence by which migration affects foreign policy outcomes. Besides a more robust test of the variance across regime type, future research may analyze how the degree to which home countries profit from their emigrants varies with the location of the diaspora; that is, whether a large diaspora in the US promises larger returns when compared to a diaspora of similar size in, for example, Russia. Furthermore, future studies may address the normatively relevant question whether diaspora activism biases aid flows, for example, by distracting aid from countries where there is more need for help, but which cannot count on the help of emigrants abroad (as suggested by Lahiri and Raimondos-Møller, 2000). While this would require a more detailed analysis of the processes by which donor governments distribute aid and the limits of allocation by fiscal constraints or fixed annual budgets, such an analysis would provide opportunities to further unpack the black box of the causal mechanisms by which diasporas affect decision-making.

Author ORCIDs. (D) Hendrik Platte, 0000-0001-7916-2659.

Supplementary Material. The supplementary material for this article can be found at https://doi.org/10.1017/psrm.2019.29

Acknowledgments. The author thanks the journal's editor, Nils Metternich, four anonymous reviewers, his supervisors Dirk Leuffen, Nils Weidmann and Michael Becher, the members of the Graduate School of Decision Sciences and attendants of MPSA 2017 and EPSA 2017 for their outstanding comments that helped to improve the article. Special thanks to David Strömberg, who kindly provided the replication material of his article with Thomas Eisensee.

\section{References}

Adamson FB and Demetriou M (2007) Remapping the boundaries of "State" and "National Identity": incorporating diasporas into IR theorizing. European Journal of International Relations 13, 489-526.

Ai C and Norton EC (2003) Interaction terms in logit and probit models. Economics Letters 80, 123-129.

Al-Yahya K and Fustier N (2011) Saudi Arabia as a Humanitarian Donor: High Potential, Little Institutionalization. SSRN Scholarly Paper ID 1789163. Rochester, NY: Social Science Research Network.

Barbieri K and Keshk OMG (2016) Correlates of war project trade data set codebook, Version 4.0.Available at http:// correlatesofwar.org/data-sets/bilateral-trade.

Barbieri K, Keshk OMG and Pollins BM (2009) Trading data: evaluating our assumptions and coding rules. Conflict Management and Peace Science 26, 471-491.

Becerra O, Cavallo E and Noy I (2015) Where is the money? Post-disaster foreign aid flows. Environment and Development Economics 20, 561-586.

Bermeo SB and Leblang D (2015) Migration and foreign aid. International Organization 69, 627-657.

Berthélemy J-C, Beuran M and Maurel M (2009) Aid and migration: substitutes or complements? World Development 37, 1589-1599.

Black R, Adger WN, Arnell NW, Dercon S, Geddes A and Thomas D (2011) The effect of environmental change on human migration. Global Environmental Change 21, Supplement 1, S3-S11.

Bostrom A, Brown D and Cechvala S (2016) Humanitarian effectiveness and the role of the diaspora: A CDA literature review. CDA Collaborative Learning Projects, Cambridge, MA. Available at http://cdacollaborative.org/publication/ humanitarian-effectiveness-role-diaspora-cda-literature-review/.

Bove V and Böhmelt T (2016) Does immigration induce terrorism? The Journal of Politics 78, 572-588.

Bove V and Böhmelt T (2019) International migration and military intervention in civil war. Political Science Research and Methods 7, 271-287.

Breunig C, Cao X and Luedtke A (2012) Global migration and political regime type: a democratic disadvantage. British Journal of Political Science 42, 825-854.

Brinkerhoff JM (2011) Diasporas and conflict societies: conflict entrepreneurs, competing interests or contributors to stability and development? Conflict, Security and Development 11, 115-143.

Dreher A, Nunnenkamp P and Thiele R (2011) Are "new" donors different? Comparing the allocation of bilateral aid between non-DAC and DAC donor countries. World Development 39, 1950-1968.

Dreher A, Fuchs A and Nunnenkamp P (2013) New donors. International Interactions 39, 402-415.

Drury AC, Olson RS and Van Belle DA (2005) The politics of humanitarian aid: U.S. foreign disaster assistance, $1964-1995$. Journal of Politics 67, 454-473.

Eisensee T and Strömberg D (2007) News droughts, news floods, and U. S. disaster relief. The Quarterly Journal of Economics 122, 693-728. 
Fink G and Redaelli S (2011) Determinants of international emergency aid-humanitarian need only? World Development 39, 741-757.

Fitzgerald J, Leblang D and Teets JC (2014) Defying the law of gravity: the political economy of international migration. World Politics 66, 406-445.

Fuchs A and Klann N-H (2012) Emergency aid 2.0. SSRN scholarly paper ID 2519635, Social Science Research Network, Rochester, NY.Available at https://papers.ssrn.com/abstract=2519635.

Gibler DM (2008) International Military Alliances, 1648-2008. Washington, DC: CQ Press.

Gleditsch KS and Ward MD (2001) Measuring space: a minimum-distance database and applications to international studies. Journal of Peace Research 38, 739-758.

Greene W (2010) Testing hypotheses about interaction terms in nonlinear models. Economics Letters 107, $291-296$.

Guha-Sapir D, Hargitt D and Hoyois P (2004) Thirty Years of Natural Disasters 1974-2003: The Numbers. Louvain-laNeuve, Belgium: Presses Universitaires de Louvain.

Harmer A and Martin E (2010) Diversity in donorship: field lessons. URL http:/lib.riskreductionafrica.org/bitstream/ handle/123456789/460/diversity $\backslash \% 20$ in $\backslash \% 20$ donorship..$\% 20$ field $\backslash \% 20 l e s s o n s . p d f ?$ sequence $=1$.

Helbling M and Leblang D (2019) Controlling immigration? How regulations affect migration flows. European Journal of Political Research 58, 248-269.

Lahiri S and Raimondos-Møller P (2000) Lobbying by ethnic groups and aid allocation. The Economic Journal 110 , 62-79.

Leblang D (2010) Familiarity breeds investment: diaspora networks and international investment. American Political Science Review 104, 584-600.

Leblang D (2017) Harnessing the diaspora: dual citizenship, migrant return remittances. Comparative Political Studies 50, 75-101.

Levitsky S and Way L (2005a) International linkage and democratization. Journal of Democracy 16, 20-34.

Levitsky S and Way LA (2005b) Ties that bind? Leverage, linkage, and democratization in the post-cold war world. International Studies Review 7, 519-524.

Márquez Peña J (2014) MORE_clarify: stata module to estimate quantities of interest through simulation and resampling methods.

Marshall MG, Gurr TR and Jaggers K (2017) Polity IV project: political regime characteristics and transitions, 1800-2016, URL http://www.systemicpeace.org/inscrdata.html.

Mayer T and Zignago S (2011) Notes on CEPII's distances measures: The GeoDist database. URL http://www.cepii.fr/cepii/ en/bdd $\_$modele/presentation.asp?id=6.

Mearsheimer JJ and Walt SM (2008) The Israel Lobby and U.S. Foreign Policy. New York: Farrar, Strauß and Giroux.

Miller GL and Ritter EH (2014) Emigrants and the onset of civil war. Journal of Peace Research 51, 51-64.

Mirilovic N (2015) Regime type, international migration, and the politics of dual citizenship toleration. International Political Science Review 36, 510-525.

Mirilovic N (2018) Regime type and diaspora politics: a dyadic approach. Foreign Policy Analysis 14, 346-366.

Olson M (1974) The Logic of Collective Action: Public Goods and the Theory of Groups. Cambridge, MA: Harvard University Press.

Özden Ç, Parsons CR, Schiff M and Walmsley TL (2011) Where on earth is everybody? The evolution of global bilateral migration 1960-2000. The World Bank Economic Review 25, 12-56.

Pérez-Armendáriz C and Crow D (2010) Do migrants remit democracy? International migration, political beliefs, and behavior in Mexico. Comparative Political Studies 43, 119-148.

Raschky PA and Schwindt M (2012) On the channel and type of aid: the case of international disaster assistance. European Journal of Political Economy 28, 119-131.

Rauch JE and Trindade V (2002) Ethnic chinese networks in international trade. Review of Economics and Statistics 84, 116-130.

Rioux J-S and Van Belle DA (2005) The influence of Le Monde coverage on French foreign aid allocations. International Studies Quarterly 49, 481-502.

Rubenzer T (2011) Campaign contributions and U.S. foreign policy outcomes: an analysis of Cuban American interests. American Journal of Political Science 55, 105-116.

Saideman SM (2002) The power of the small: the impact of ethnic minorities on foreign policy. SAIS Review 22, 93-105.

Salehyan I and Gleditsch KS (2006) Refugees and the spread of civil war. International Organization 60, 335-366.

Shain Y and Barth A (2003) Diasporas and international relations theory. International Organization 57, 449-479.

Silva JMCS and Tenreyro S (2006) The log of gravity. Review of Economics and Statistics 88, 641-658.

Singer JD and Small M (1966) Formal alliances, 1815-1939: a quantitative description. Journal of Peace Research 3, $1-31$.

Smith T (2000) Foreign Attachments: The Power of Ethnic Groups in the Making of American Foreign Policy. Cambridge, MA: Harvard University Press.

Tierney MJ (2016) AidDataCore_researchrelease_level1_v3.0. URL http://aiddata.org/sites/default/files/inline/readme.pdf. 
Tierney MJ, Nielson DL, Hawkins DG, Roberts JT, Findley MG, Powers RM, Parks B, Wilson SE and Hicks RL (2011) More dollars than sense: refining our knowledge of development finance using AidData. World Development 39, 18911906.

Wooldridge JM (2010) Econometric Analysis of Cross Section and Panel Data. Cambridge, MA/London, England: MIT Press. Yang D (2008) Coping with disaster: the impact of hurricanes on international financial flows, 1970-2002. The B.E. Journal of Economic Analysis and Policy 8, 1-45.

Cite this article: Platte H (2021). No calm after the storm-diaspora influence on bilateral emergency aid flows. Political Science Research and Methods 9, 275-291. https://doi.org/10.1017/psrm.2019.29 